\title{
MANAJEMEN PENDIDIKAN KARAKTER BERBASIS PONDOK PESANTREN DARUSSYIFA AL-FITHROH YASPIDA SUKABUMI
}

\section{MANAGEMENT OF CHARACTER EDUCATION BASED ON BOARDING SCHOOL DARUSSYIFA AL-FITHROH YASPIDA SUKABUMI}

\author{
M Yusup1a, 0 Abdurakhman', dan RSP Fauziah'1 \\ ${ }^{1}$ Program Studi Manajemen Pendidikan Islam, Fakultas Keguruan dan Ilmu Pendidikan, \\ Universitas Djuanda Bogor, Jl. Tol Ciawi No. 1 Kotak Pos 35 Ciawi Bogor 16720 \\ a Korespondensi: Muhamad Yusup, Email: yusup.paspamda@gmail.com \\ (Diterima: 08-03-2018; Ditelaah: 08-03-2018; Disetujui: 16-04-2018)
}

\begin{abstract}
Character education has meaning high of moral education, because character education is not only concerned with the problem of right or wrong, but how to instill habits (habituation) about the good things in life, so that students have an awareness, sensitivity, and high understanding, as well as the awareness and commitment to implement policies in everyday life. The purpose of this research is to be able to know how to do the planning, deploy, and evaluating character education to be well applied properly and targeted data collected by the ethnographic method approach taken by digging through interviews or questionnaires to the students. The findings show that the management of character education in schools is not maximized in its application. It is characterized by the lack of discipline of the students in learning, worship, and social views. Therefore, the holding of the renewal of the guidance to the organization uniquely Islamic boarding school as the driving discipline students. This research resulted in the conclusion that the management of schools character education is how to build discipline in students four aspects of life that view, learning, worship, and association that all of them will be the key to success.
\end{abstract}

Keywords: management, character education, islamic boarding school.

\begin{abstract}
ABSTRAK
Pendidikan karekter bukan hanya berhubungan dengan benar atau salah, tetapi bagaimana menanamkan kebiasaan (habituation) dalam kehidupan sehari-hari, sehingga santri memiliki kesadaran, kepekaan, kepedulian, dan komitmen untuk menerapkan kebijakan dalam kehidupannya. Tujuan dari penelitian ini adalah agar dapat mengetahui cara melakukan perencanaan, pelaksanaan, dan pengevaluasian pendidikan karakter agar dapat teraplikasikan dengan baik dan benar serta tepat sasaran. Data yang dikumpulkan dengan metode etnografi yakni dengan menggali informasi lewat wawancara atau kuesioner kepada para santri. Hasil temuan menunjukkan bahwa pendidikan karakter di Pondok Pesantren Salafiyah Darussyifa Al-Fithroh Yaspida Sukabumi minim dalam pengaplikasiannya. Hal tersebut ditandai dengan kurang disiplinnya para santri dalam pembelajaran, peribadahan, tampilan, dan pergaulan. Maka seharusnya diadakan pembaharuan terhadap pembinaan kepada para organisasi kepesantrenan sebagai penggerak kedisiplinan santri. manajemen pendidikan karakter pesantren adalah bagaimana membangun kedisiplinan dalam empat aspek kehidupan santri yaitu tampilan, pembelajaran, peribadahan, dan pergaulan yang semuannya akan menjadi kunci keberhasilan dan kesuksesan.
\end{abstract}

Kata kunci: manajemen, pendidikan karakter, pondok pesantren. 
Yusup, M., Abdurakhman, O., \& Fauziah, R. S. P. (2018). Manajemen Pendidikan Karakter Berbasis Pondok Pesantren Darussyifa Al-Fithroh Yaspida Sukabumi. Tadbir Muwahhid, 2(1), 11-24.

\section{PENDAHULUAN}

Kata Manajemen berasal dari Bahasa Inggris "manage", yang memiliki arti seni melaksanakan dan mengatur. Manajemen belum memiliki definisi yang mapan dan diterima secara universal. Mary Parker Follet, misalnya, mendefinisikan manajemen sebagai seni menyelesaikan pekerjaan melalui orang lain. Definisi ini berarti bahwa seorang manajer bertugas mengatur dan mengarahkan orang lain untuk mencapai tujuan organisasi. Ricky W. Griffin mendefinisikan manajemen sebagai sebuah proses perencanaan, pengorganisasian, pengkoordinasian, dan pengontrolan sumber daya untuk mencapai sasaran secara efektif dan efesien. Efektif berarti bahwa tujuan dapat dicapai sesuai dengan perencanaan, sementara efisien berarti bahwa tugas yang ada dilaksanakan secara benar, terorganisir, dan sesuai dengan jadwal (Mulyasa, 2006). Sehingga, manajemen adalah elemen-elemen dasar yang akan selalu ada dan melekat di dalam proses manajemen yang akan dijadikan acuan oleh manajer dalam melaksanakan kegiatan untuk mencapai tujuan.

Fungsi manajemen pertama kali diperkenalkan oleh seorang industrialis Perancis bernama Henry Fayol pada awal abad ke-20. Ketika itu, ia menyebutkan lima fungsi manajemen, yaitu merancang, mengorganisir, memerintah, mengordinasi, dan mengendalikan. Namun saat ini, kelima fungsi tersebut telah diringkas menjadi tiga yaitu: 1) Perencanaan (planning), adalah memikirkan apa yang akan dikerjakan dengan sumber yang dimiliki. Perencanaan dilakukan untuk menentukan tujuan perusahaan secara keseluruhan dan cara terbaik untuk memenuhi tujuan itu. Manajer mengevaluasi berbagai rencana alternatif sebelum mengambil tindakan dan kemudian melihat apakah rencana yang dipilih cocok dan dapat digunakan untuk memenuhi tujuan perusahaan. Perencanaan merupakan proses terpenting dari semua fungsi manajemen karena tanpa perencanaan, fungsi-fungsi lainnya tak dapat berjalan; 2) Pengorganisasian (organizing), dilakukan dengan tujuan membagi suatu kegiatan besar menjadi kegiatan-kegiatan yang lebih kecil. Pengorganisasian mempermudah manajer dalam melakukan pengawasan dan menentukan orang yang dibutuhkan untuk melaksanakan tugas yang telah dibagi-bagi tersebut. Pengorganisasian dapat dilakukan dengan cara menentukan tugas apa yang harus dikerjakan, siapa yang harus mengerjakannya, bagaimana tugas-tugas tersebut dikelompokkan, siapa yang bertanggung jawab atas tugas tersebut, dan pada tingkatan mana keputusan harus diambil; 3) Pengevaluasian (evaluating), yaitu proses pengawasan dan pengendalian performa lembaga untuk memastikan jalannya lembaga sesuai dengan rencana yang telah ditetapkan (Mulyasa, 2012).

Pendidikan pada dasarnya merupakan upaya pembudayaan dan pemberdayaan untuk menumbuh kembangkan potensi dan kepribadian peserta didik sehingga mereka dapat menjadi pribadi yang cerdas, berakhlak mulia, dan memiliki kemampuan dan keterampilan yang berguna bagi dirinya, masyarakat, bangsa, dan negara. 
Pendidikan ingin mengembangkan potensi peserta didik yang utuh, seimbang, dan berkesinambungan, tidak hanya dimensi intelektual tetapi juga dimensi spritual, karakter, kinestesik, sosial serta keterampilan yang diperlukan sebagai warga masyarakat dan warga negara.

Krisis karakter dewasa ini sangat memperihatinkan dikarenakan pembinaan karakter yang dilakukan dalam lembaga pendidikan hanya sedikit sekali, yaitu pada mata pelajaran pendidikan agama islam saja. Kementrian pendidikan dan kebudayaan memuat delapan belas pembiasaan karakter. Semua pembiasaan karakter sudah diaplikasikan di pesantren dengan pengawasan yang dilaksanakan dan dipantau oleh kyai sebagai pemilik serta pengurus pondok. Kunci dari keberhasilan penerapan dari karakter yang diaplikasikan adalah kedisiplinan. Disiplin adalah bagaimana kehidupan sehari-hari dilakukan tepat waktunya.

Akan tetapi dalam penerapannya, disiplin belum terwujud dalam perilaku santri. dalam kehidupan santri, banyak yang melakukan indisipliner dalam kehidupan sehari-hari baik dalam kegiatan makan, sholat berjam'aah, sekolah, mengaji, dan lain-lain. Banyak kesimpulan yang diambil oleh para pengurus yang dilaporkan kepada pimpinan pondok pesantren, seperti: 1) tidur kemalaman; 2) kegiatan yang padat (dikarenakan santri mengikuti pembelajaran mengaji dan sekolah sampai pukul 20.00), dan lainnya. akan tetapi, meskipun demikian bukan alasan untuk menjadi insan yang disiplin, dikarenakan jika santri dapat memenej waktu dengan baik maka kedisiplinan akan tercipta. Dengan disiplin maka delapan belas nilai karakter yang disampaikan oleh Kemendikbud akan terealisasikan dan akan maksimal dalam penerapannya.
Dari kedelapan belas nilai karakter yang sudah rumuskan oleh Kemendikbud, ada satu nilai karakter yang belum maksimal pengaplikasiannya yaitu nilai karakter cinta tanah air baik kepada pondok, maupun kepada negara. Dalam penelitian santri yang berjumlah empat puluh orang. Maka, para santri berjumlah dua puluh empat orang $(60 \%)$ menjawab belum merasakan nasionalisme tentang kebangsaan, kemahadan, dan kedaerahan. Adanya pernyataan diantara santri yang belum mengalami keharmonisan seperti saling mencela daerah, bahasa, bahkan pekerjaan orang tua.

Istilah pesantren menurut H.A.R. Gibb adalah javanese "santri-place", seminary for students of teology (santri) on the islands of Java and Madura (tempat santri Jawa, seminari teologi bagi santri di Pulau Jawa dan Madura). Sedangkan menurut Dhofie berasal dari kata "santri", yang dengan awalan "pe" di depan diakhirkan "an" (menjadi pesantren) yang berarti tempat tinggal para santri. Di dalamnya pelajar (santri) mengikuti pelajaran agama islam. Demikian juga Ziemek menyebutkan bahwa asal etimologi dari pesantren adalah pesantri-an, yang artinya "tempat santri" (Abdullah, 2014).

Pengertian pondok pesantren secara terminologi juga cukup banyak dikemukakan oleh para tokoh. Beberapa tokoh tersebut diantaranya: 1) Nasir, mendefinisikan bahwa pondok pesantren adalah lembaga keagamaan yang memberikan pendidikan dan pengajaran serta mengembangkan dan menyebarkan ilmu agama Islam (Nasir, 2013); 2) Rabithah Ma'ahid Islamiyah (RMI), mendefinisikan pesantren sebagai lembaga tafaqquh fi al-dîn yang mengembangkan misi meneruskan risalah Muhammad SAW sekaligus melestarikan ajaran Islam yang 
berhaluan Ahlu al-sunnah wa al- Jama'ah 'ala Thariqah al-Mazahib al-'Arba'ah (Hariadi, 2015).

Pimpinan pesantren menegaskan kunci keberhasilan dalam kehidupan di tengahtengah masyarakat adalah dengan moralitas. Mengamati dari dekat perilaku santri, jelas pendidikan karakter di Pondok Pesantren Salafiyah Terpadu Darussyifa AlFithroh Yaspida Sukabumi dipusatkan pada pendalaman dan penghayatan agama, lengkap dengan pengamalannya dalam perilaku keseharian.

\section{MATERI DAN METODE}

\section{Metode Penelitian}

Metode yang digunakan dalam penelitian ini menggunakan pendekatan etnografi yang memperlakukan realitas objektif sebagai hasil yang interaksional dan diskursif; deskripsi, cerita, atau laporan tidak sematamata berkisah tentang dunia sosial, ketiganya adalah unsur pembentuk dunia tersebut (Moleong, 2008). Pendekatan yang dilakukan tidak dimaksudkan untuk menggali informasi lewat wawancara atau kuesioner, namun mengandalkan percakapan yang terjadi secara alami untuk menjelaskan bagaimana interaksi seharihari memproduksi tatanan sosial di dalam konteks berlangsungnya percakapan tersebut. Ujaran subjek atau informan dipandang sebagai tindakan yang menciptakan realitas lokal itu sendiri. Etnografi berfokus pada penyediaan analisis rasional struktur, prosedur, dan strategi yang digunakan masyarakat sendiri ketika mereka membuat rasa keluar dari dunia sehari-hari mereka sendiri dan tindakan dan interaksi.

Penelitian ini dilaksanakan di Pondok Pesantren Darussyifa Al-Fitroh Yaspida
Sukabumi. Alasan dipilihnya pondok pesantren ini adalah karena mengingat sejarah dan pendidikan karakter yang khas dan kontinyu yang selalu diajarkan kepada para santri baik tingkat bawah maupun tingkat tinggi. Pondok Pesantren Darussyifa Al-Fitroh Yaspida Sukabumi, merupakan lembaga pendidikan swasta yang dibentuk secara khusus untuk membentuk akhlak para santri yang ada dilingkungan pondok pesantren. Penelitian yang dipakai oleh peneliti adalah jenis deskriptif kualitatif yang mempelajari masalah-masalah yang ada serta tata cara kerja yang berlaku.

Jenis dan sumber data yang digunakan dalam penelitian ini adalah data kualitatif. Data kualitatif yaitu data yang tidak berupa angka-angka, melainkan diuraikan dalam bentuk kalimat. Adapun data kualitatif meliputi 1) data tentang gambaran umum mengenai objek penelitian; dan 2) data lain yang tidak berupa angka.

Jenis-jenis sumber data yang digunakan dalam penelitian ini dibagi menjadi dua macam, yaitu sumber data primer dan sumber data sekunder. Sumber data primer dalam penelitian ini merupakan data yang diperoleh dari informan yaitu orang yang berpengaruh dalam proses perolehan data atau bisa disebut key member yang memegang kunci sumber data penelitian ini, karena informan benar-benar tahu dan terlibat dalam kegiatan yang ada di sekretariatan Pondok Pesantren Darussyifa Al-Fitroh Yaspida Sukabumi. Adapun yang menjadi informan dalam penelitian ini antara lain: Sekretaris Yayasan, Kepala Bagian Kepesantrenan, dan Kepala Pembina Kepesantrenan. Penetapan informan ini dilakukan dengan mengambil orang yang telah terpilih oleh peneliti menurut ciri-ciri spesifik yang dimiliki oleh sampel atau memilih sampel yang sesuai dengan tujuan penelitian. Hal tersebut dinamakan teknik 
purposive sampling yaitu sampel yang dipilih dengan cermat hingga relevan dengan design penelitian. Peneliti akan berusaha agar dalam sampel itu terdapat wakil-wakil dari segala lapisan populasi sehingga dapat dianggap cukup representatif.

Sedangkan untuk data yang lain berasal dari hasil observasi dan dokumentasi. Observasi dilakukan dengan cara melakukan pencatatan secara cermat dan sistematik. Observasi langsung yang dilakukan oleh peneliti dengan cara mencatat berupa informasi yang berhubungan dengan pondok pesantren. Juga mengamati bagaimana kegiatan di pondok pesantren. Dengan observasi secara langsung, peneliti dapat memahami konteks data dalam berbagai situasi, maksudnya dapat memperoleh pandangan secara menyeluruh. Sedangkan untuk data dokumentasi diperoleh dengan cara melihat kembali sumber-sumber data dari dokumen yang ada dan dapat digunakan untuk memperluas data-data yang telah ditemukan. Adapun sumber data dokumen diperoleh dari lapangan berupa buku, arsip, majalah bahkan dokumen perusahaan atau dokumen resmi yang berhubungan dengan fokus penelitian.

\section{Teknik Analisis Data}

Tahap menganalisa data adalah tahap yang paling penting dan menentukan dalam suatu penelitian. Data yang diperoleh selanjutnya dianalisa dengan tujuan menyederhanakan data ke dalam bentuk yang lebih mudah dibaca dan diinterpretasikan. Selain itu data diterjunkan dan dimanfaatkan agar dapat dipakai untuk menjawab masalah yang diajukan dalam penelitian.

Dalam penelitian ini berlandaskan pada analisa induktif. Peneliti berusaha merumuskan pernyataan atau abstraksi teoritis lebih umum mendasarkan peristiwa. Induksi analisis yang menghasilkan proposisi-proposisi yang berusaha mencakup setiap kasus yang dianalisis dan menghasilkan proposisi interaktif universal. Salah satu ciri penting induksi analisis adalah tekanan pada kasus negatif yang menyangkut proposisi yang dibangun peneliti. Analisis ini dilakukan berdasarkan pengamatan di lapangan atau pengalaman empiris berdasarkan data yang diperoleh dari wawancara, observasi, dan dokumentasi kemudian disusun dan ditarik kesimpulan.

Untuk memperoleh tingkat keabsahan data, teknik yang digunakan antara lain:

1. Ketekunan pengamatan, yakni serangkaian kegiatan yang dibuat secara terstruktur dan dilakukan secara serius dan berkesinambungan terhadap segala realistis yang ada di lokasi penelitian dan untuk menemukan ciri-ciri dan unsur-unsur di dalam situasi yang sangat relevan dengan persoalan atau peristiwa yang sedang dicari kemudian difokuskan secara terperinci dengan melakukan ketekunan pengamatan mendalam. Maka dalam hal ini peneliti diharapkan mampu menguraikan secara rinci berkesinambungan terhadap proses bagaimana penemuan secara rinci tersebut dapat dilakukan.

2. Triangulasi data, yakni teknik pemeriksaan keabsahan data yang memanfaatkan sesuatu yang lain di luar data yang terkumpul untuk keperluan pengecekan atau sebagai pembanding terhadap data-data tersebut. Hal ini dapat berupa penggunaan sumber, metode penyidik, dan teori. Dari berbagai teknik tersebut cenderung menggunakan sumber, sebagaimana disarankan oleh patton yang berarti membandingkan dan mengecek kembali 
derajat kepercayaan suatu data yang diperoleh melalui waktu dan alat yang berbeda dalam metode kualitatif. Untuk itu untuk melihat keabsahan data dilakukan dengan cara sebagai berikut: a) Membandingkan hasil wawancara dan pengamatan dengan data hasil wawancara; b) Membandingkan hasil wawancara dengan isi suatu dokumen yang berkaitan; dan c) Membandingkan apa yang dikatakan orang secara umum dengan apa yang dikatakan secara pribadi. Yang ingin diketahui dari perbandingan ini adalah mengetahui alasan-alasan apa yang melatarbelakangi adanya perbedaan tersebut (jika ada perbedaan) bukan titik temu atau kesamaannya sehingga dapat dimengerti dan dapat mendukung validitas data.

3. Diskusi teman sejawat, yakni diskusi yang dilakukan dengan rekan yang mampu memberikan masukan ataupun sanggahan sehingga memberikan kemantapan terhadap hasil penelitian. Teknik ini digunakan agar peneliti dapat mempertahankan sikap terbuka dan kejujuran serta memberikan kesempatan awal yang baik untuk memulai menjejaki dan mendiskusikan hasil penelitian dengan teman sejawat. Oleh karena itu pemeriksaan sejawat ini dilakukan melalui diskusi dan bersifat informal dengan maksud agar dapat memperoleh kritikan yang tajam untuk membangun dan penyempurnaan pada kajian penelitian yang sedang dilaksanakannya.

\section{HASIL DAN PEMBAHASAN}

\section{Hasil}

Pendidikan karakter yang diteliti adalah karakter Cinta Tanah Air. Cinta Tanah Air dalam bahasa Arab disebut al-wathaniyyah (kebangsaan) atau hub al-wathan (nasionalisme). Pecinta nusa bangsa disebut nasionalis (Poerwadarminta, 2006). Cinta sendiri maknanya berjenjang sesuai kualitas dan intensitas yang diekspresikan. Ada beberapa penjelasan mengenai tingkatan cinta, yaitu: 1) Tingkat cinta terendah adalah yafrah lifarhika wa yakhzanu likhuznika, rasa yang membuat seseorang bahagia jika yang tercinta bahagia, dan risau jika ia gundah gulana; 2) Tingkatan selanjutnya ditambah dengan takhallalat mahabbatuhu bi-adha'ik, rasa cintanya telah merasuk ke jiwa-raga; 3) Tingkatan yang paling puncak ditambah dengan wa yubdihi bi-malik dan memebrikan segala yang dimiliki untuk yang dicintai. Jadi, tingkatan pertama berupa simpati dan empati, yang kedua, tingkatan dimanifestasikan melalui ekspresi cinta, yang ketiga tingkatan terakhir melibatkan pengorbanan, baik harta-benda maupun jiwa.

Cinta tanah air dalam sejarah para nabi dan rasul, di mana mereka mencintai tanah air melebih cinta mereka pada diri sendiri. Ada banyak jejak dan bukti sejarah, karena cinta diungkapkan dengan pembuktian dan tak sekerdar ucapan yang dicontohkan oleh Nabi Ibrahim yaitu sennatiasa berusaha dan berdoa agar tanah airnya aman, damai, dan diberkahi dengan ekonomi yang makmur. Salah satu doa Nabi Ibrahim yang diabadikan di dalam al-Quran berbunyi: "Dan (ingatlah) ketika Ibarahim berdoa, 'Ya Tuhanku, jadikanlah negeri ini negeri yang amna sentosa, dan berikanlah rezeki dari buah-buahan kepada penduduknya yang beriman di antara mereka kepada Allah dan hari kemudian. Allah berfirman,'dan kepada orang yang kafir pun aku beri kesenangan sementara,'”' (QS. Al-Baqarah:126)

Ada dua hal yang diidam-idamkan Nabi Ibrahim atas tanah airnya: pertama, balada 
amin atau negeri yang aman dan damai bagi penduduknya; kedua, war-zuq ahlahu, yaitu negara yang penduduknya makmur secara ekonomi dan tidak dilanda krisis. Bahkan Allah SWT menjanjikan bahwa kedamaian dan kemakmuran akan dilimpahkannya tidak hanya untuk yang beriman kepadaNya, namun juga bagi seluruh penduduk termasuk yang tidak beriman sekaipunkarena kasih sayang-Nya meliputi seluruh umat manusia, baik muslim maupun nonmuslim tanpa pandang bulu. Nabi Muhamad SAW pun sangat mencintai tanah airnya. Hal ini dibuktikan, ketika hendak berangkat hijrah dari Mekah ke Madinah beliau berkata, "Alangkah besar cintaku pada kota Mekah, tempat kelahiran dan tumpah darahku. Andaikan saja penduduknya tidak mengusirku, maka pasti akau akan tetap berada di kota Mekah."

Pimpinan pesantren memandang bahwa kunci sukses dalam hidup bersama adalah moral agama, serta para ulama pesantren telah merumuskan konsep persaudaraan yang terjalin antar sesama muslim (ukhuwwah islamiyyah), antar sesama anak bangsa (ukhuwwah wathaniyyah) dan antar sesama manusia (ukhuwwah basyariyyah). Konsep persaudaraan ini dirumuskan oleh KH. Achmad Siddiq, pimpinan Pondok Pesantren as-Siddiqiyah di Jembar, mantan ketua Rais Suriyah PBNU dan sekretaris pribadi KH. Wahid Hasyim pada tahun 1950. KH. Abdurrahmman Wahid (Gus Dur) kemudian menyebarluaskan, memberi pemaknaan lebih mendalam, dan menerapkan konsep tersebut dalam pergaulan sosial yang lebih luas, di mana seluruh ulama pesantren pun ikut mengamini langkah tersebut.

Persaudaraan sebangsa dan senegara (ukhuwwah wathaniyyah) merupakan ruh bagi cinta tanah air. Para kyai pesantren menyadari bahwa bangsa Indonesia berasal dari berbagai suku, bahasa, adat-istiadat dan agama serta kepercayaan, dan meskipun berbada-beda, mereka semuanya bersaudara. Sebagai saudara sebangsa, kalangan pesantren tidak memusuhi perbedaan atau mereka yang dipandang berbeda, karena bangsa ini dibangun secara bersama-sama. Pesantren pun menunjukan kecintaan terhadap tanah air dengan turut serta dalam perjuangan meraih kemerdekaan dan pembangunan Indonesia.

Persaudaraan sebangsa dan senegara adalah diwujudkan dengan bagaimana rakyat dalam mengamalkan nilai karakter cinta tanah air di Indonesia. selain itu, nilai karakter cinta tanah air adalah bagaimana dia memiliki kedisiplinan dalam kehidupannya dengan disiplin santri dapat mematuhi, menaati peraturan baik di sekolah, keluarga, maupun masyarakat atas dasar kesadaran dan pemahaman yang muncul dari dalam diri sendiri. Bahkan. Di Pondok Pesantren Darussyifa Al-Fitroh Yaspida Sukabumi, ada empat pilar kedisplinan untuk membentuk karakter para santri terutama nilai cinta tanah air. Empat pilar tersebut adalah disiplin dalam tampilan, disiplin dalam peribadahan, disiplin dalam pembelajaran, dan disiplin dalam pergaulan. Semuannya hasil dari ijtihad Kyai Yaspida dalam upaya merealisasikan seluruh peraturan, visi dan misi pondok pesantren.

\section{Pembahasan}

\section{Manajemen Pendidikan Karakter}

Manajamen (pengaturan), kata ini merupakan derivasi dari kata dabbara (mengatur) yang banyak terdapat dalam AlQuran seperti firman Allah SWT.

"Dia mengatur segala urusan dari langit ke bumi, kemudian (urusan) itu naik kepadaNya dalam satu hari yang kadarnya 
(lamanya) adalah seribu tahun menurut perhitunganmu" (Q.S. As-Sajdah: 5).

\section{Ariestoteles dalam tulisannya}

berpendapat bahwa pembiasaan karakter itu dilihat dari tingkah lakunya sendiri. Pendidikan karakter adalah upaya yang disengaja untuk memahami manusia, peduli, dan inti atas nilai-nilai etis atau susila (Gunawan, 2012). Upaya tersebut diatur dalam manajemen pendidikan karakter yang dimulai dengan: 1) perencanaan, memikirkan apa yang harus dilakukan dan dituangkan dalam bentuk tulisan agar semuanya dalam satu organisasi dapat melihat; 2) pengorganisasian, melakukan mengelompokan anggota agar pekerjaan dapat terlaksana dengan baik, tepat waktu, dan efeisiensi; 3) pengevaluasian, dimana mengevaluasi semuan kegiatan dari awal sampai akhir.

Perencanaan pendidikan karakter nilai cinta tanah air di Pondok Pesantren Darussyifa Al-Fitroh Yaspida Sukabumi, direncanakan dengan pembaharuan dalam pembinaan kepada organisasi yang ada di lingkup pondok pesantren. Di Pondok Pesantren Darussyifa Al-Fitroh terdapat banyak organisasi yang menjadi kepanjang tanganan kyai dalam mengelola pondok. Pembinaan terhadap organisasi dilakukan secara bertahap sesuai jadwal yang telah dijadwalkan oleh pihak pondok. Dalam pembinaan selalu dihadirkan pemateri dari kalangan mudabir atau mudaris pondok, bahkan kyai pondok pun ikut dalam pembinaan pada organisasi pondok.

Ada banyak organisasi pondok diantaranya Paspamda (Pasukan Pengaman Yaspida), Pasgarda ( Pasukan Gabungan Anak Aider Responsif Yaspida Sukabumi), Dewan Ma'had, Dewan Santri, Dewan Asatidz, As-syaidah, Roisam, Rois dan Roisah, serta organisasi yang ada dilingkungan sekolah yaitu OSIS, PMR,
Pramuka, drum band, marawis, dan hadroh Yaspida Sukabumi.

Dalam kajian nilai cinta tanah air pondok pesantren memiliki tiga organisasi seperti Paspamda, Pasgarda, dan As-Syaidah yang berkerja sama langsung dengan stukpa lemdikpol dan kodim TNI 0607 . Dimana dua institusi pemerintahan ini langsung membina dalam segi kedisiplinan, moral serta mental para santri yang mengikuti organisasi tersebut.

Dalam perencanaan, dimulai dengan melakukan koordinasi dengan pihak pesantren. Hal yang dilakukan yaitu dengan cara menyerahkan draf jadwal pembinaan untuk seluruh organisasi kepesantrenan. Dengan tujuan agar organisasi di pondok mendapatkan bimbingan dan selalu terayomi demi terwujudnya keselarasan dan keharmonisan antara mudabir, mudaris, dan pengurus organisasi. Perencanaan pembinaan keorganissian yang sudah ditandatangani oleh pimpinan pondok pesantren Dr. KH. E. Supriatna Mubarok, M.Sc. MM., Hj. Lani Melani. M.M.Pd., dan H. Said HR., S.Ag. yang memuat seluruh jadwal pembinaan dari organisasi yang ada.

Selain pembentukan jadwal pembinaan, juga dilakukan pembentukan organisasi kesantrian yang sudah ada sejak tahun 2005, yaitu Dewan Santri yang merupakan organisasi yang menjadi induk dari seluruh organisasi yang ada di pondok. Pembentukan organisasi dimulai dengan demonstrasi calon presiden dan wakil. Dewan Santri dilaksanakan pada tanggal 16 Februari 2017 tepat pada pukul 20.00 WIB. Dewan Santri terdiri dari para santri yang duduk di tingkat kelas tiga Sekolah Menengah Atas/Kejuruan (SMA/SMK). Tujuan dibentuknya Dewan Santri adalah sebagai tangan kanan kyai dalam hal penegakan kedisiplinan di pondok 
pesantren. Keberhasilan penanaman pendidikan karakter nilai cinta tanah air di Pondok Pesantren Darussyifa Al-Fitroh berhulu dan hilir dalam hal kedisiplinan.

Setelah pelaksanaan demonstrasi, maka pada tanggal 17 Februari 2017 tepat pada pukul 20.00 WIB, dilaksanakan pemilihan dengan pencoblosan sebagai perealisasian dari nilai karakter demokrasi. para pemilih terdiri dari para mudabir, mudaris, santri tingkat pertama, tingkat atas/kejuruan, dan para mahasiswa. Semuannya memilih sebagai warga pondok yang sadar akan demokrasi.

Nilai cinta tanah air harus diaplikasikan dan direalisasikan. Dalam pelaksanaannya, nilai cinta tanah air di Pondok Pesantren Darussyifa Al-Fitroh Yaspida Sukabumi, diaplikasikan dengan peralisasian seluruh perencanaan yang sudah direncanakan dengan pihak pondok pesantren yaitu pembinaan kepada organisasi yang ada di lingkungan pondok pesantren seperti Paspamda, Pasgarda, As-Syaidah, Dewan Santri, Dewan Mahad, Rois dan Roisah, Laskar Amanah Negeri-Ku, Markaz Sholawat, dan masih banyak yang lainnya. Pelaksanaan pembinaan ini sudah disetujui langsung oleh Dr. KH. E. Supriatna Mubarok, M.Sc., MM. (Dewan Pembina Perguruan Yaspida Sukabumi), Hj. Lani Melani, M.Pd. (Ketua Umum Yayasan Sosial Dan Pendidikan Islam Darussyifa Al-Fitroh), Dan H. Said HR., S.Ag. (Dewan Penasehat Kepesantrenan), yang di dalamnya sudah tercantum jadwal pembinaan dari tempat, waktu, serta pemateri yang semuannya sudah disetujui oleh para pimpinan organisasi tersebut. Dalam pelaksanaannya, pembinaan diintegrasikan dengan pendidikan karakter yang sudah menjadi budaya di pondok pesantren.

Selain dalam pembinaan, kegiatan pembelajaran dari tahapan kegiatan pendahuluan, inti, dan penutup dipilih dan dilaksanakan agar santri mempraktikan nilai-nilai karakter yang ditargetkan. Prinsip-prinsip Contextual Teaching and Learning disarankan dan diaplikasikan pada semua tahap pembelajaran. Membina kedisiplinan santri harus mempertimbangkan berbagai situasi, dan memahami faktor-faktor yang memengaruhinya. Oleh karena itu, disarankan kepada guru untuk melakukan hal-hal sebagai berikut: 1) Memulai seluruh kegiatan dengan disiplin waktu, dan patuh pada aturan; 2) Mempelajari pengalaman santri di pondok melalui catatan kumulatif; 3) Mempelajari nama-nama santri secara langsung, misalnya melalui daftar hadir di kelas pengajian; 4) Mempertimbangkan lingkungan pembelajaran dan lingkungan santri; 5) Memberikan tugas yang jelas, dapat dipahami, sederhana, dan tidak bertele-tele; 6) Menyiapkan kegiatan seharihari agar apa yang dilakukan dalam pembelajaran sesuai dengan yang direncanakan, tidak terjadi banyak penyimpangan; 7) Bergairah dan bersemangat dalam melakukan pembelajaran, agar dijadikan teladan oleh santri; dan 8) Berbuat sesuatu yang berbeda dan bervariasi, jangan monoton, sehingga membantu disiplin dan gairah belajar santri di pondok.

Melalui berbagai upaya tersebut diharapkan tercipta iklim yang kondusif bagi implementasi pendidikan karakter, sehingga santri dapat menguasai berbagai kompetensi sesuai tujuan pendidikan di pondok. Diantara pembiasaan yang dapat dilakukan di pondok yaitu terbiasa senyum ramah pada orang lain dan teman, dan pembiasaan-pembiasaan lain yang menjadi aktivitas sehari-hari santri. Untuk bisa melakukannya memang menuntut orang tua dan guru bisa menjadi teladan pertama dan 
utama bagi santri. Jadi jika ingin membiasakan santri kita taat aturan maka kita perlu menjadi pertama lebih dahulu taat aturan. Perlu diingat bahwa ketika melakukan proses pembiasaan, disiplin, dan ketelatenan harus konsisten dan berkesinambungan, jangan kadang dilakukan kadang tidak. Hal itu akan mempersulit keberhasilan pendidikan karakter.

Setelah perencanaan, maka kegiatan manajemen selanjutnya adalah pelaksanaan pendidikan karakter nilai cinta tanah air secara optimal, diorganisasikan, dan dikelola sedemikian rupa. Sedikitnya terdapat lima hal yang perlu dilaksanakan di pondok pesantren seperti pelaksanaan pembelajaran untuk membekali santri tentang pendidikan karakter nilai cinta tanah air, pengadaan dan pembinaan kepada organisassi kepesantrenan, pendayagunaan lingkungan dan sumber daya masyarakat pondok, pengembangan dan penataan kebijakan pondok pesantren kepada organisasi di lingkungan pesantren, serta keterbatasan pembelajaran nilai cinta tanah air.

\section{Pelaksanaan Pembelajaran}

Pembelajaran berkarakter di pondok pesantren dilaksanakan berdasarkan kebutuhan dari organisasi yang ada di lingkungan pesantren, pembelajaran berkarakter yang sudah diaplikasikan perlu mempertimbangkan hal-hal sebagai berikut: 1) Mengintegrasikan karakter dalam setiap pembeleajaran yang diaplikasikan dengan kehidupan masyarakat di sekitar pondok dan rumah; 2) Mengidentifikasikan karakter sesuai dengan kebutuhan yang dirasakan oleh santri; 3) Mengembangkan indikator setiap karakter agar relevan dengan perkembangan dan kebutuhan santri; 4) Menata struktur dan mekanisme kerja yang jelas serta mejalin kerja sama di antara fasilator dan tenaga kependidikn dengan sekolah atau pondok lain dalam pembentukan karakter di pondok; 5) Merekrut anggota organisasi yang memiliki pengetahuan, keterampilan, dan sikap cinta tanah air; 6) Melengkapi sarana prasarana belajar yang memadai yang berhubungan dengan nilai cinta tanai air serta membangun kedisiplinan santri dalam segala bidang kehidupan dan penghidupannya; 7) Menilai program kerga secara berkala dan berkesinambungan untuk melihat keefektifan pembentukan karakter. Disamping itu, penilaian juga penting untuk meilihat apakah pembelajaran dengan pengaplikasian dikembangakan dan diterapkan dalam mengembangkan potensi santri.

Selain dalam pembinaan, kegiatan pembelajaran mulai dari tahapan penduluan, inti, dan penutup dipilih dan dilaksanakan agar santri mempraktikan nilai-nilai karakter yang ditargetkan. Prinsip-prinsip Contextual Teaching and Learning disarankan diaplikasikan pada semua tahap pembelelajaran karena prinsip-prinsip pembelajaran tersebut sekaligus dapat memfasilitasi terinternalisasinya nilai-nilai. Selain itu, perilaku mudaris sepanjang proses pembelajaran harus merupakan model pelaksanaan nilai-nilai bagi santri.

Strategi pondok pesantren agar pembelajaran tepat sasaran dan nilai karakter dapat terwujud dan teraplikasikan adalah: 1) Pembiasaan rajin dalam ketaatan peribadahan; 2) Pembiasaan sopan dan santun dalam pergaulan; 3) Pembiasaan kesederhanaan dalam kehidupan; 4) Pembiasaan kekhusyuan dalam pencarian ilmu; 5) Pembiasaan semangat dalam pekerjaan dengan landasan kerja keras, kerja cerdas, kerja ikhlas, kerja tuntas, kerja 
mawas, dan kerja puas; dan 6) Pembiasaan ketawadhuan dalam kehidupan sehari-hari.

Selain strategi yang sudah direalisasikan oleh pengurus pondok, yang dimana strategi tersebut adalah hasil ijtihad dari kyai pondok pesantren Dr. KH. E. Supriatna Mubarok, M.Sc., MM., selanjutnya ada lima pilar manajemen kepesantren yang wajib dipegang oleh para mudabir dan mudaris pondok pesantren yaitu manajemen pengasuhan, manajemen pengayoman, manajemen pengajaran, manajemen pembinaan, dan manajemen pengawasan. Kemudian, metode pembinaan organisasi kepesantrenan dilakukan dengan memberikan masukan kepada pesantren agar setiap guru di pondok pesantren menggunakan RPP berkarakter serta pengurus pesantren merumuskan silabusnya. Dengan demikian, kegiatan dapat berjalan dengan harmonis sesuai dengan nilai karakter yang dicetuskan oleh Kemendikbud, sehingga tercipta empat pilar kesisiplinan santri Pondok Pesantren Darussyifa Al-Fitroh Yaspida Sukabumi yang terdiri dari disiplin tampilan, disiplin pembelajaran, disiplin peribadahan, dan disiplin pergaulan. Dengan kedisiplinan tersebut makan tercipta serta terealisasinya visi dan misi Pondok Pesantren Darussyifa Al-Fitroh Yaspida Sukabumi.

Visi Pondok Pesantren Darussyifa AlFitroh Yaspida Sukabumi adalah mencetak santri yang intek, religius, cerdas, berakhlaqul karimah, mandiri, kompetitif, disiplin dalam segala hal menuju insan kamil anfa'ahum linnas melalui pengkaderan ulamaul amilin. Dengan visi tersebut maka pondok pesantren menjabarkannnya dengan misi pondok yaitu: 1) Menanamkan nilai-nilai keislaman dan akhlaqul karimah serta aqidah islamiyah ahlusunah wa jamaah; 2) Mengembangkan minat dan bakat satri melalui kurikulum kepesantrenan berbasis keterpaduan, kompetensi, kemasyarakatan, dan aplikasi amaliyah ubudiyah; 3) Mendalami ilmu pengetahuan dan teknologi serta karyakarya seni yang islami; 4) Memberikan pelayanan dan keteladanan atas dasar nilainilai islami yang inklusif dan humanis; 5) Mengembangkan manajemen pesantren berbasis keterpaduan, yang menjadi rujukan secara regional dan nasional; 6) Mengembangkan kemitraan dengan institusi pemerintahan, lembaga kemasyaraatan, lembaga usaha, dan swadaya tanpa ada ikatan; 7) Menyiapkan generasi santri yang mampu menghadapi segala tantangan zaman dengan berprilaku secara islami; 8) Melaksanakan amanah aqliyah ahlusunah wal jamaah melalui pengembangan pendidikan berbasis keterpaduan secara kualitatif dan kuantitatif; dan 9) Menjadikan pondok pesantren sebagai tempat mengabdi untuk umat menuju mardotillah. Dari visi dan misi tersebut, maka pondok pesantren memiliki moto "santri Darussyifa, berakhlaq mulia, berwawasan cendikia, budaya hidup sederhana dan madani".

Dalam rangka menyukseskan pendidikan karakter di pondok pesantren, perlu didayagunakan lingkungan dan sumber daya masyrakat pondok pesantren secara optimal seperti seluruh organisasi kelembagaan dan kesatrian dilingkungan pondok pesantren. Untuk kepentingan tersebut, para guru dan fasilator dituntut untuk mendayagunakan lingkungan, baik lingkungan fisik maupun lingkungan sosial, serta menjalin kerja sama dengan unsurunsur pemerintahan seperti dalam kajian nilai cinta tanah air pondok pesanren yang memiliki tiga organisasi seperti Paspamda, Pasgarda dan As-Syaidah yang berkerja sama langsung dengan Stukpa Lemdikpol dan Kodim 0607. Dimana dua institusi 
pemerintahan ini langsung membina dalam segi kedisiplinan, moral. serta mental para santri yang mengikuti organisasi tersebut.

Implementasi pendidikan karakter di pondok pesantren perlu didukung oleh kebijakan-kebijakan pondok pesantren sebagai penyelenggara pendidikan. Kebijakan yang jelas dan baik akan dapat memberikan kelancaran dan kemudahan dalam implementasi pendidikan karakter nilai cinta tanah air. Ada beberapa kebijakan yang relevan diambil pihak pondok pesantren dalam membentuk kelancaran pendidikan karakter nilai cinta tanah air, yaitu sebagai berikut: 1) Memprogramkan perubahan program kerja organisasi sebagai bagian integral dari program pondok secara keseluruhan; 2) Menganggarkan biaya operasioanl pondok pesantren untuk kegiatan dan pelatihan organisasi di luar pondok atau latihan gabungan serta kunjungan kepada pondok lain demi terciptanya sinergisitas dan mewujudkan pengalaman yang lebih jauh dan memperluas silaturahmi; 3) Meningkatkan mutu dan kualitas pembina agar dapat membina secara proporsional dalam pemberian materi kepada para santri dan organisasi; 4) Menyediakan sarana prasarana yang baik untuk kepentingan belajar dan pembentukan karakter; 5) Menjalin kerja sama yang lebih luas dengan instansi-instansi pemerintahan yang lain. Tujuannya, agar materi dan ilmu tidak didapatkan dari satu atau dua institusi saja.

Dalam pendidikan karakter, penilaian harus ditunjukan untuk mengetahui tercapai tidaknya standar dan indikator yang telah ditetapkan oleh organisai pondok pesantren. Penilaian dapat dilakukan terhadap program, proses, dan hasil belajar. Penilaian program bertujuan untuk menilai efektivitas program yang dilaksanakan. Penilaian proses bertujuan untuk mengetahui aktivitas dan partisipasi santri dalam pembelajaran, sedangkan penilaian hasil tujuan untuk mengetahui hasil belajar atau pembetukan kompetensi dan karakter santri.

\section{Keberhasilan Pembinaan Organisasi}

Setelah dilihat dari dua bulan terakhir setelah pembinaan dilakukan, yakni pada Bulan Januari dan Februari, maka proses pembinaan dikatakan berhasil, dilihat dari hasil di Bulan Februari. Dari perbandingan skala bertingkat, Bulan Januari ke Bulan Februari menunjukan adanya kemajuan dari Bulan Januari dengan persentase 90\%. Dinsamping itu para santri yang mengikuti organisasi menunjukan kegairahan yang tinggi, semangat dalam pembinaan, dan meningkatkan rasa percaya diri saat mengikuti organisai masing-masing. Dalam nilai cinta tanah air, sebelumnya hanya $60 \%$ santri dapat merasakan nilai cinta tanah air yang khidmat. Dengan diadakan pembinaan nilainya naik menjadi 90\%, kenaikan ini mengambarkan keberhasilan dari pembinaan karakter.

Dalam hal ini, para santri yang mengikuti organisai yang sudah mendapatkan pembinaan dari para pembina bisa mengajak santri yang lain, yaitu santri yang biasanya tidak peduli dengan keadaan pondoknya baik dalam kebersihan, kenyamanan, dan ketertiban. Akan tetapi, sekarang mereka dapat mengajak para santri yang lain dalam gorong royong dalam kebersihan pondok dan lingkungannya. Paspamda, Pasgarda, dan As-Syaidah pun dahulu yang tidak disiplin dalam melaksanakan tugas ketertibannya, setelah mengikuti pembinaan yang sudah dilakukan dalam kurun waktu dua bulan ini, maka terlihat perubahan dengan semakin disiplinnya dalam ketertiban dan penjangaan pondok. 


\section{KESIMPULAN DAN IMPLIKASI}

\section{Kesimpulan}

Berdasarkan hasil penelitian terhadap manajemen pendidikan karakter nilai cinta tanah air di Pondok Pesantren Darussyifa Al-Fitroh Yaspida Sukabumi. Dengan melakukan penelitian lapangan serta wawancara terhadapt pengasuh pesantren yakni kepala kepesantrenan dan pembina kepesantrenan, maka peneliti mendapatkan sebuah hasil bahwa pendidikan karakter yang Kemendikbud sudah tuangkan yaitu ada 18 nilai karakter sudah diaplikasikan serta diajarkan kepada para santri. Akan tetapi ada satu nilai karater yang memang belum maksimal dalam pengaplikasiannya yaitu nilai cinta tanah air. Maka kesimpulan ditarik dengan memperhatikan hal-hal sebagai berikut: 1) Perencanaan pendidikan karakter nilai cinta tanah air di Pondok Pesantren Darussyifa Al-Fitroh Yaspida Sukabumi direncanakan dengan pembaharuan dalam pembinaan kepada organisasi kepesantrenan seperti Paspamda, Pasgarda, As-Syaidah, Dewan Santri, Dewan Mahad, Laskar Amanah Negeri-Ku, Markaz Sholawat, dan lainnya. Pembinaan adalah hal yang sangat penting dalam organisasi dikarenakan dengan adanya pembinaan yang kontinyu kepada organisasi kesantrian selain tiga organisasi tersebut, maka akan mendorong organisasi semakin berperan dan menjadi kepanjangtanganan kyai dalam mengelola pondok. Selain itu, jadwal pembinaan terlebih dahulu diserahkan kepada pihak kepesantrenan agar bisa diberikan kepada bapak sesepuh pondok dan ibu ketua umum yayasan agar bisa disetujui dan disahkan yang selanjutnya diumumkan kepada seluruh santri. Selain jadwal pembinaan, penulis juga membantu dalam pembentukan Dewan Santri yang telah menjadi icon kesantrian tingkat atas yang sudah didirikan pada tahun 2005. Penulis berkumpul dengan para ketua angkatan tingkat atas untuk dapat menjadi bagian serta menyukseskan demokrasi pemilihan Dewan Santri dengan perumusan, mekanisme acara, dan lainnya; 2) Pelaksanaan pendidikan karakter nilai cinta tanah air di Pondok Pesantren Darussyifa Al-Fitroh Yaspida Sukabumi adalah dengan merealisasikan jadwal pembinaan yang sudah disetujui oleh bapak sesepuh pondok dan ibu ketua umum yayasan yang di dalamnya tercantum waktu, tempat, dan pemateri yang akan dilaksanakan dalam pembinaan sesuai tanggalnya. Selain itu, pemilihan Dewan Santri yang sudah direncanakan dengan pimpinan angkatan direalisasikan dengan meriah yang dihadari oleh para mudabir dan mudaris pondok pesantren. Pendidikan karakter nilai cinta tanah air adalah manifestasi dari disiplin karena dengan disipilin pergaulan, peibadahan, pembelajaran, serta tampilan yang selalu dikemukan oleh pimpinan pondok adalah kunci dari keberhasilan dan kesuksesan; 3) Penilaian dari pendidikan karakter nilai cinta tanah air di Pondok Pesantren Darussyifa Al-Fitroh Yaspida Sukabumi, dilakukan dengan menggunakan wawancara dengan beberapa anggota organisasi yang dilakukan dengan wawancara dan observasi. Dengan melihat langsung bagaimana antusias santri dalam menyerap ilmu dan mengaplikasikannya kepada santri lain. Selain itu pemantauan, langsung dari perubahan santri sebelum dan sesudah diberikan pembinaan.

\section{Implikasi}

Dari hasil penelitian ini dapat dikembangkan penelitian serupa tentang manajemen pendidikan karakter berbasis Pondok Pesantren Darussyifa Al-Fithroh 
Yaspida Sukabumi dalam perencanaan, pengorganisasian, pelaksanaan, dan pembinaan guna mencapai tujuan lembaga yang bermutu sesuai yang diamanhkan oleh pancasila, undang-undang 1945 dan visimisi lembaga.

\section{DAFTAR PUSTAKA}

Abdullah, B. (2014). Manajemen Pendidikan Islam. Bandung: Pustaka Setia.

Gunawan, H. (2012). Pendidikan Karakter Konsep dan Implementasi. Bandung: Alfabeta.
Hariadi. (2015). Evolusi Pesantren. Yogyakarta: Lkis Printing. Moleong, L. J. (2008). Metodologi Penelitian Kualitatif. Bandung: Remaja Rosdakarya. Mulyasa. (2006). Manajemen Berbasis Sekolah. Bandung: Remaja Rosdakarya. Mulyasa. (2012). Manajemen Pendidikan Karakter. Jakarta: Bumi Aksara.

Nasir, H. (2013). Pendidikan Karakter Berbasis Agama dan Budaya. Yogyakarta: Multi Presindo.

Poerwadarminta. (2006). Kamus Umum Bahasa Indonesia. Jakarta: Balai Pustaka. 